\title{
Transfusion and risk of infection in Canada: Update 2005
}

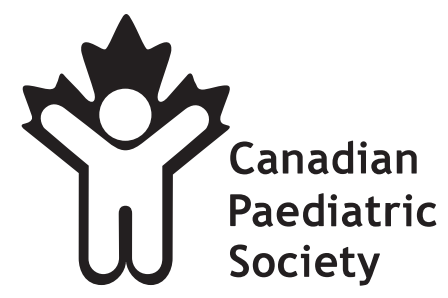

I n Canada and other countries, many steps are taken to minimize the risk of infection through the transfusion of blood or blood products (1). However, the infection risk can never be zero because these are biological products that are taken from living donors who are never 'germ free' (2). This is in contrast to drugs that can be manufactured de novo under sterile conditions in a laboratory. The present note provides an update on transfusion infection risks in Canada. It replaces the 2004 note (3) and may be helpful to practitioners in discussions with patients and parents toward obtaining informed consent before blood or blood product administration.

A crucial step in enhancing safety is to carefully assess whether the patient will likely benefit from the administration of blood or blood products (ie, that the potential benefit outweighs the potential risks) (4). For example, a study in critically ill adults (5) showed that, in terms of outcomes, a restrictive transfusion policy in which red blood cells were transfused only if the hemoglobin concentration dropped below $70 \mathrm{~g} / \mathrm{L}$ and hemoglobin concentrations were maintained at $70 \mathrm{~g} / \mathrm{L}$ to $90 \mathrm{~g} / \mathrm{L}$ is at least as effective and possibly superior to a liberal transfusion strategy in which red blood cells are transfused if the hemoglobin concentration fell below $100 \mathrm{~g} / \mathrm{L}$ and hemoglobin concentration maintained at $100 \mathrm{~g} / \mathrm{L}$ to $120 \mathrm{~g} / \mathrm{L}$. Similarly, a preliminary report has shown that a restrictive transfusion policy in very low birth weight infants (ie, hemoglobin kept in the range of $115 \mathrm{~g} / \mathrm{L}$ to $75 \mathrm{~g} / \mathrm{L}$ versus a more liberal policy with the range of $135 \mathrm{~g} / \mathrm{L}$ to $85 \mathrm{~g} / \mathrm{L}$ in high group) appears to be safe (6). The ongoing Transfusion Transmitted Injuries Surveillance System in Canada (Table 1), which looks for serious adverse events with receiving of blood or blood product infusions, has found that while there is a high degree of safety, there

\section{TABLE 1}

Types of adverse transfusion reactions*

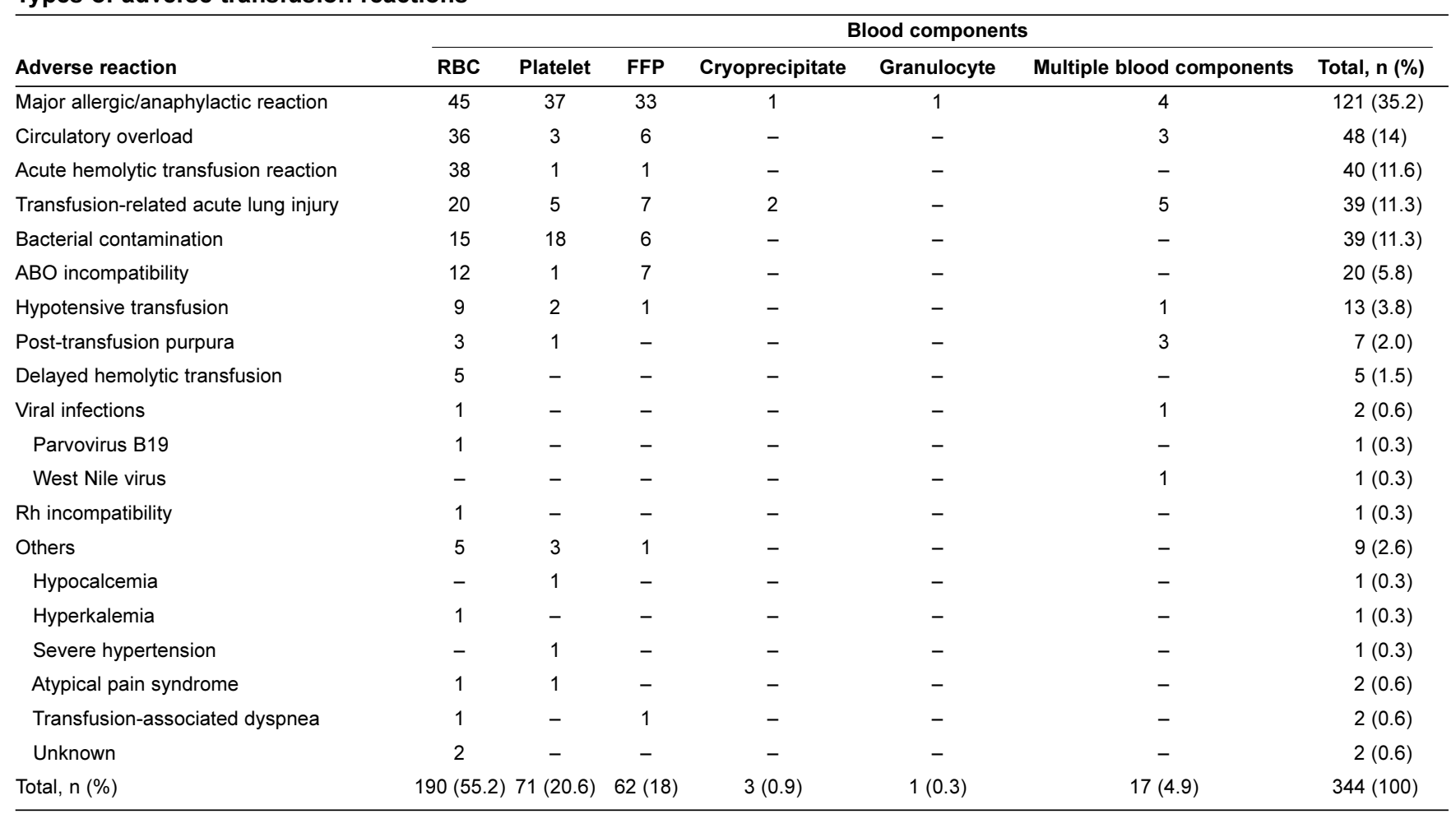

${ }^{*}$ Data from the Transfusion Transmitted Injuries Surveillance System program from April 1, 2001 to December 31, 2003 (Dr A Giulivi, Ms Nancy McCombie, personal communication). FFP Fresh frozen plasma; RBC Red blood cell

Correspondence: Dr Noni MacDonald, Department of Paediatrics, IWK Health Centre, 5840 University Avenue, Halifax, Nova Scotia

B3J 3G9. Telephone 902-470-8799, fax 902-470-7812, e-mail noni.macdonald@dal.ca 
are still risks (albeit small) of both infection and other adverse events such as transfusion-related acute lung injury $(7,8)$.

Besides the careful assessment of need, prior immunization with hepatitis $\mathrm{B}$ vaccine is an additional way to minimize risk from infection with this blood-borne pathogen for those who are likely to receive multiple blood transfusions in an elective situation.

While any infectious agent that has a blood phase has the potential to be transmitted by the transfusion of blood or blood products, the probability of infection in the recipient depends on a number of factors, including $(5,9,10)$ :

- The prevalence of the agent in the blood of the donor population;

- The tolerance of the agent to blood handling, storage and manufacturing procedures;

- The infectivity and pathogenicity of the agent;

- The recipient's health status;

- The effectiveness of donor screening or donor testing for the agent; and

- The effectiveness of the aseptic technique used in collecting the blood or blood product from the donor and in infusing the product into the recipient.

In Canada, the infectious disease risks of transfusion are minimized through multiple steps, including blood collection from volunteer unpaid donors, donor interview and

\section{TABLE 2}

Testing of blood donors in Canada* by Canadian Blood Services (CBS) and Héma-Québec

\begin{tabular}{ll}
\hline HIV-type $1 / 2^{\dagger}$ group & Antibody/nucleic acid testing \\
Hepatitis B virus & HbsAg, Anti-HBc ${ }^{\ddagger}$ \\
HTLV type I/II & Antibody \\
Syphilis & Treponemal test/PK-TP \\
Hepatitis C virus & Antibody/nucleic acid testing \\
West Nile virus & Nucleic acid testing \\
Other§ & CMV antibody on selected units only \\
\hline
\end{tabular}

*Dr Gilles Delage, Héma-Québec and Dr Heather Hume, CBS, personal communications; ' While the PRISM HIV antibody test does detect HIV group O, donors are still asked questions related to travel to parts of the world where HIV-O infection is prevalent, until a change in practice is approved; $¥$ Antibody to hepatitis $B$ core antigen (Anti-HBC) testing was introduced by HémaQuébec in 2003 and will be introduced by CBS in 2005; \$Héma-Québec and CBS are developing bacterial culture testing for apheresis platelets. CMV Cytomegalovirus; HbsAg Hepatitis B surface antigen; HTLV Human T-lymphotropic viruses selection procedures, careful aseptic technique procedures for collection and infusion, diversion of the first $40 \mathrm{~mL}$ of blood collected into a diversion pouch, donor screening by serological and other tests (Table 2) (including donor screening for West Nile virus [WNV] since 2003) (11), and viral inactivation procedures included in the manufacturing of plasma-derived products (Table 2) (12-15).

With WNV donor screening testing now in place, the risk of contamination in blood collected from donors during a WNV outbreak is estimated to be $1 / 400,000$ to $1 / 600,000$ or less (3). This measure reflects the sensitivity of the test and the prevalence of infection among donors in a given region. The incidence of WNV in Canada last year was low in all regions. During the 2004 WNV season, with the use of the screening process, no blood or blood product infusion related cases of WNV were detected.

As noted in Table 3, solvent/detergent procedures dissolve the lipid envelope of HIV, WNV, hepatitis B virus and hepatitis $\mathrm{C}$ virus, but they are not effective against nonlipidenveloped viruses such as hepatitis A virus or parvovirus B19. Heat inactivation is effective against a wide range of viruses, including WNV, hepatitis A virus and parvovirus (15). The leukocyte reduction technique that is used by Canadian Blood Services and Héma-Québec to further improve the safety of the blood supply also reduces the infection transmission risk, particularly for cytomegalovirus (CMV) (14).

Table 4 identifies specific inactivation steps in the manufacture of different plasma-derived products that decrease viral infection risks. Of note, the majority of Factor VIII and Factor IX used in Canada are recombinant products that are not plasma derived and, hence, do not have the infectious risks of a blood product.

Unfortunately, the solvent/detergent and heat viral inactivation procedures noted in Table 3 cannot be used on red blood cells or platelets because neither can withstand these vigorous viral inactivation processes. Bacterial contamination of platelets is also a risk (greater than that with red blood cells) because platelets are stored at room temperature $\left(22^{\circ} \mathrm{C} \pm 2^{\circ} \mathrm{C}\right)$, which supports bacterial pathogen multiplication $(16,17)$. Various strategies have been developed to try to minimize the risk of transfusion-associated sepsis, including enhanced aseptic collection and handling procedures (diversion pouches are now in place), pretransfusion bacterial detection systems, processing and storage enhancement procedures, and pathogen inactivation techniques (18).

TABLE 3

Specific manufacturing procedures for virus inactivation or removal

\begin{tabular}{lll}
\hline Procedure & Agents inactivated & Agents not inactivated \\
\hline Inactivation by heat & $\mathrm{CMV}, \mathrm{HAV}, \mathrm{HBV}, \mathrm{HCV}, \mathrm{HIV}$, WNV, parvovirus B19 & HAV, parvovirus B19, enteroviruses \\
Inactivation by solvent/detergent & $\mathrm{CMV}, \mathrm{HBV}, \mathrm{HCV}, \mathrm{HIV}, \mathrm{WNV}$ & \\
Ultrafiltration using $35 \mathrm{~nm}$ and $15 \mathrm{~nm}$ filters & Removes even small viruses but also macromolecules
\end{tabular}

Ultrafiltration using $35 \mathrm{~nm}$ and $15 \mathrm{~nm}$ filters Removes even small viruses but also macromolecules

(eg, Factor VIII is decreased)

Leukocyte depletion

Decreases CMV, HTLV type I, II

Non-WBC-associated viruses

CMV Cytomegalovirus; HAV Hepatitis A virus; HBV Hepatitis B virus; HCV Hepatitis C virus; HTLV Human T-lymphotropic viruses; WBC White blood cell; WNV West Nile virus 
TABLE 4

Manufacturing steps to decrease infectious risks of plasma preparations and plasma-derived components

\begin{tabular}{|c|c|c|c|}
\hline \multirow{2}{*}{$\begin{array}{l}\text { Plasma preparation } \\
\text { Cryoprecipitate (a blood component - } \\
\text { not a fractionation product) }\end{array}$} & $\begin{array}{l}\text { Virus risk } \\
\text { preinactivation } \\
\text { process(es) }\end{array}$ & \multirow{2}{*}{$\begin{array}{c}\text { Pools screened } \\
\text { for HIV, HCV, HBV, } \\
\text { and HTLV type I, II* } \\
\text { Yes }\end{array}$} & \multirow{2}{*}{$\begin{array}{l}\text { Further virus inactivation steps } \\
\text { None }^{\dagger}\end{array}$} \\
\hline & $-\quad++$ & & \\
\hline Factor VII & + & Yes & Heat inactivation \pm solvent/detergent \\
\hline Factor VIII & + & Yes & Heat inactivation \pm solvent/detergent \\
\hline Factor IX & + & Yes & Heat inactivation, solvent/detergent, chromatography, ultrafiltration \\
\hline Albumin & + & Yes & Cohn fractionation, heat inactivation \\
\hline Intravenous immunoglobulin products & + & Yes & $\begin{array}{l}\text { Cohn fractionation, } \pm \text { hydrolase, } \pm \text { solvent/detergent, } \pm \text { heat inactivation } \\
\pm \text { chromatography, nanofiltration, } \pm \text { caprylate }\end{array}$ \\
\hline Intramuscular immunoglobulin & + & Yes & Cohn fractionation, solvent/detergent, heat treatment, nanofiltration, \pm chromatography \\
\hline Specific antibody products $\ddagger$ & + & Yes & $\begin{array}{l}\text { Cohn fractionation or ion exchange column chromatography, solvent/detergent, } \\
\text { filtration } \pm \text { heat inactivation }\end{array}$ \\
\hline
\end{tabular}

*Human T-lymphotropic viruses (HTLV) type I/II are cell-associated viruses, so they are not found in manufactured plasma-derived products and serological screening of source plasma is not required. Similarly, cytomegalovirus is primarily cell-associated and the manufacturing processes remove risk; ${ }^{\dagger}$ Hence, the risk of transmission of infection from cryoprecipitate is similar to the risk from blood and blood products, and greater than the risk from plasma-derived manufactured products; $\ddagger$ eg, Hepatitis B virus (HBV) immune globulin, tetanus immune globulin, rabies immune globulin, Rh (D) immune globulin, etc. HCV Hepatitis $C$ virus

TABLE 5

Bacterial agents associated with acute infection during blood product transfusion

\begin{tabular}{lll}
\hline Blood component & Storage & Bacterial agent \\
\hline Packed red cells & $1^{\circ} \mathrm{C}$ to $6^{\circ} \mathrm{C}$ for & Yersinia enterocolitica and \\
& 35 to 42 days & $\begin{array}{l}\text { other Gram-negative } \\
\text { organisms, including } \\
\text { Pseudomonas species }\end{array}$ \\
Whole blood & $1^{\circ} \mathrm{C}$ to $6^{\circ} \mathrm{C}$ for & Gram-negative organisms \\
& 35 to 42 days & \\
Platelets & $20^{\circ} \mathrm{C}$ to $24^{\circ} \mathrm{C}$ for & Skin flora (eg, Staphylococcus \\
& 5 days & epidermidis diphtheroids), \\
& & Salmonella species, \\
& & Escherichia coli, \\
& & Enterococcus species, \\
& & Clostridium species, \\
Flasma & Frozen, once thawed & Staphylococcus aureus and \\
can be held at $1^{\circ} \mathrm{C}$ & Pseudomonas aeruginosa \\
to $6^{\circ} \mathrm{C}$ for $24 \mathrm{~h}$ &
\end{tabular}

In 2005, Canadian Blood Services will begin to implement the buffy coat method for the preparation of platelet pools with pretransfusion bacterial culture testing. Almost all reported acute infectious complications arising from blood product transfusion are associated with bacterial pathogens (16-18) (Table 5 and Figure 1). While the use of closed multicomponent plastic blood pack collection systems has helped to decrease the problem, contamination of platelet concentrates is still a concern $(16,17)$. The risk of bacterial contamination of frozen components such as fresh frozen plasma and cryoprecipitates is low because the usual microbes (Table 5) are killed by freezing and other storage conditions. Where plasma has been found to be the source of infection, this was usually due to contamination of the water bath used to thaw the product (19). The use of microwave techniques or appropriate plastic covering specifically designed for this purpose minimizes this risk.

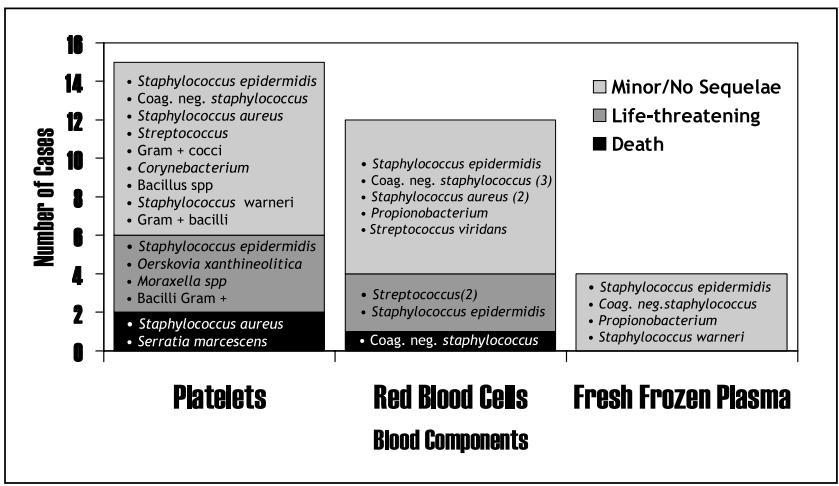

Figure 1) Definite and probable cases of bacterial contamination (April 1, 2001 to September 30, 2003). Data from the Transfusion Transmitted Injuries Surveillance System program (Dr A Giulivi, Ms Nancy McCombie, personal communication). Coag neg Coagulasenegative

The estimated per unit risk of contamination in blood, blood products and manufactured plasma-derived products in Canada for a number of viral, bacterial, parasitic, prion and tick-borne agents are presented in Tables 6 and 7. In cases where Canadian data are not available, data from the United States and other countries have been included $(4,9,13,20-21)$. As the data in Tables 7 and 8 show, the risks in Canada of transmitting infectious agents by blood, and especially, by plasma-manufactured products, are extremely low. To put it in context, a 1/3,000,000 risk is similar to that of being hit by lightning.

The risk estimates for the transmission of CMV remain complex (22). Although $40 \%$ to $70 \%$ of donors are CMVpositive, the risk of disease in nonimmunocompromised recipients is very low, while the risk of disease in immunocompromised and transplant patients is significant. For CMV seronegative recipients receiving seronegative organs or allogenic marrow, the risk of CMV infection in solid organ transplant recipients and in bone marrow transplant 
TABLE 6

Estimated risk of infectious agent blood or blood products

\begin{tabular}{|c|c|c|c|}
\hline $\begin{array}{l}\text { Agents and } \\
\text { products }\end{array}$ & $\begin{array}{l}\text { Transfusion- } \\
\text { transmitted }\end{array}$ & Pathogenic & $\begin{array}{l}\text { Canadian estimated risk of } \\
\text { contamination }^{*}\end{array}$ \\
\hline \multicolumn{4}{|c|}{ Viruses for which all blood donors are tested } \\
\hline $\mathrm{HIV}^{\dagger}$ & Yes & Yes & $<1 / 4,000,000$ \\
\hline Hepatitis C virus ${ }^{\dagger}$ & Yes & Yes & $<1 / 3,000,000$ \\
\hline Hepatitis $B$ virus ${ }^{\dagger}$ & Yes & Yes & $1 / 275,000$ to $1 / 1,000,000$ \\
\hline HTLV† types I, II & Yes & Yes & $<1 / 4,000,000$ \\
\hline \multicolumn{4}{|l|}{ Other viruses } \\
\hline Cytomegalovirus & Yes & Yes & $\begin{array}{l}\text { Risks vary with donor/ } \\
\text { recipient }^{\ddagger}\end{array}$ \\
\hline Parvovirus B19 & Yes & Yes & $1 / 10,000$ to $1 / 15,000$ \\
\hline GB virus $\mathrm{C}^{\dagger \S}$ & Yes & Unknown & $\begin{array}{l}1-2 \text { in } 100 ; \text { not known to } \\
\text { be pathogenic }\end{array}$ \\
\hline TTV $^{\dagger}$ & Yes & Unknown & $1 / 100$; rarely pathogenic \\
\hline SEN virus ${ }^{\dagger}$ & Yes & Unknown & $\begin{array}{l}\text { 1/100; not known to be } \\
\text { pathogenic }\end{array}$ \\
\hline $\mathrm{HHV}-8^{\dagger}$ & Unknown & Yes & Unknown \\
\hline West Nile virus & Yes & Yes & $\begin{array}{l}1 / 400,000 \text { to } 1 / 600,000 \\
\text { during outbreak }\end{array}$ \\
\hline \multicolumn{4}{|l|}{ Parasites } \\
\hline Malaria & Yes & Yes & $\begin{array}{l}4 \text { cases reported in Canada } \\
\text { in the past } 10 \text { years }\end{array}$ \\
\hline $\begin{array}{l}\text { Chagas } \\
\text { (Trypanosoma cruz }\end{array}$ & ruzi) & Yes & $\begin{array}{l}2 \text { cases reported in Canada } \\
\text { in past } 15 \text { years }\end{array}$ \\
\hline $\begin{array}{l}\text { Babesiosis } \\
\text { (Babesia microti) }\end{array}$ & Yes & Yes & $\begin{array}{l}1 \text { case reported in Canada } \\
\text { in the past } 15 \text { years }\end{array}$ \\
\hline \multicolumn{4}{|l|}{ Prion } \\
\hline vCJD & Unknown & Yes & $<1 / 10,000,000$ \\
\hline
\end{tabular}

${ }^{*}$ Risk of contamination refers to the potential residual risk of infection from the listed organisms in blood or blood products after proper screening and manufacturing processes have occurred; ${ }^{\dagger}$ Based on $3 \%$ to $5 \%$ of the Canadian population from the 17- to 65-year-old age group being blood donors. Based on reported cases from Public Health. Based on sensitivity and specificity of the tests used at Canadian Blood Services and Héma-Québec; ${ }^{\ddagger}$ Cytomegalovirus infection risk is decreased by leukoreduction procedures (see text); §Formerly named Hepatitis G virus; "IWest Nile virus risk of 1/100,000 to 3/100,000 during an outbreak is an estimation given the sensitivity of the screening test and the prevalence of donor infection during an outbreak. HHV-8 Human herpes virus 8; HTLV Human T-lymphotropic viruses; TTV Transfusion transmitted virus; vCJD Variant Creutzfeldt-Jakob disease

recipients is $2 \%$ to $3 \%$ and $20 \%$ to $50 \%$, respectively, when non-WBC-reduced, unscreened blood components are given $(14,22)$. This risk can be decreased with selection for seronegative donors and/or the use of leukocyte depletion filters (eg, the estimated risk of CMV infection for a bone marrow transplant recipient is only $2.4 \%$ when a leukocyte depletion filter is used) (14).

Although the risk of transmission of infectious agents through blood and plasma products is very low, the possibility of risk with a new or previously unrecognized agent is always present. Hence, an assessment of the potential transfusion risk must be made when a new agent is discovered or when new evidence comes to light. The two reports in 2004 from the United Kingdom of the possible transmission of variant Creutzfeldt-Jakob disease (one recipient asymptomatic) by transfusion of red blood cells donated by
TABLE 7

Estimated risks of infectious agents in manufactured plasma-derived products

\begin{tabular}{|c|c|c|c|}
\hline $\begin{array}{r}\text { Histo } \\
\text { of } t \\
\text { fr }\end{array}$ & $\begin{array}{l}\text { rical evidence } \\
\text { ransmission } \\
\text { om plasma } \\
\text { product }\end{array}$ & Pathogenic & $\begin{array}{l}\text { Canadian estimated risk of } \\
\text { contamination }^{*}\end{array}$ \\
\hline \multicolumn{4}{|c|}{ Viruses for which all blood donors are tested } \\
\hline HIV & Yes & Yes & Less than $1 / 10$ million \\
\hline Hepatitis $\mathrm{C}$ virus & Yes & Yes & Less than $1 / 10$ million \\
\hline Hepatitis $B$ virus & Yes & Yes & Less than $1 / 10$ million \\
\hline HTLV types I, II & Yes & Yes & Only theoretical risk \\
\hline \multicolumn{4}{|l|}{ Other viruses } \\
\hline Cytomegalovirus & No & Yes & Only theoretical risk \\
\hline Parvovirus B19 & Yes & Yes & $\begin{array}{l}\text { Only theoretical risk if heat } \\
\text { inactivated; otherwise, } \\
1 / 100,000 \text { to } 1 / 1,000,000\end{array}$ \\
\hline West Nile virus & No & Yes & $\begin{array}{l}\text { Much lower than } 1 / 600,000, \\
\text { only theoretical risk }\end{array}$ \\
\hline \multicolumn{4}{|l|}{ Parasites } \\
\hline Malaria & No & Yes & Only theoretical risk \\
\hline Chagas & No & Yes & Only theoretical risk \\
\hline Babesiosis & No & Yes & Only theoretical risk \\
\hline \multicolumn{4}{|l|}{ Prion } \\
\hline vCJD & Unknown & Yes & $\begin{array}{l}\text { Theoretical risk of less than } \\
1 / 100,000,000\end{array}$ \\
\hline
\end{tabular}

${ }^{*}$ Risk of contamination refers to the potential residual risk of infection from the listed organisms in plasma-derived products after proper screening and correct manufacturing processes have taken place. HTLV Human T-lymphotropic viruses; vCJD Variant Creutzfeldt-Jakob disease

individuals 3.5 years and 18 months before the donors developed symptoms $(23,24)$ combined with other evidence lead to a reassessment of the variant CreutzfeldtJakob disease transfusion risk and a shift of the risk from a theoretical possibility to a real, albeit very low, risk $(25,26)$.

The experience gained from hepatitis C and HIV traceback and look-back programs, in which authorities have tried to trace transfusion recipients, have shown that many patients are unaware that they actually received a transfusion. No national electronic record of transfusions yet exists to facilitate any potential future tracing programs for a new transmittable agent. Therefore, it is important to ensure that transfused patients are aware that they received blood, blood products or manufactured plasma-derived products, and that the discharge or outpatient note adequately documents these transfusions and records the label code numbers for the specific products used.

The Transfusion Transmitted Injuries Surveillance System noted above, which has now been expanded to include all provinces and territories except Nunavut, will lead to an improvement in the quality and timeliness of risk estimates for blood-related infectious diseases and injuries. This system will provide firmer evidence for Canadian risk estimates that will be useful for providing counselling for informed consent.

The parent handout titled "When you child needs a transfusion" is available on our Web site <www.caringforkids.cps.ca>. 


\section{REFERENCES}

1. Strong DM, Katz L. Blood bank testing for infectious diseases: How safe is blood transfusion? Trends Mol Med 2002;8:355-8.

2. Murphy WG. Disease transmission by blood products: Past, present and future. Pathophysiol Haemost Thromb 2002;32(Suppl 1):1-4.

3. Canadian Paediatric Society, Infectious Diseases and Immunization Committee. Transfusion and risk of infection in Canada: UPDATE 2004. Paediatr Child Health 2004;9:145-8.

4. Kleinman S, Chan P, Robillard P. Risks associated with transfusion of cellular blood components in Canada. Transfus Med Rev 2003; 17:120-62.

5. Hebert PC, Wells G, Blajchman MA, et al. A multicenter, randomized, controlled clinical trial of transfusion requirements in critical care. N Engl J Med 1999;340:409-17. (Erratum in 1999;340:1056).

6. Kirpalani H, Whyte R, Anderson C, et al. Conservative Transfusion Regimens are Not Associated With Higher Mortality or Morbidity in ELBW Infants - The Premature In Need of Transfusion (PINT) Randomized Controlled Trial. Pediatric Academic Societies meeting, San Francisco, May 1-4, 2004.

7. Blood Safety Surveillance and Health Care Acquired Infections Division, Population and Public Health Branch, Health Canada. Transfusion Transmitted Injuries Surveillance Report 2001-2002. <www.hc-sc.gc.ca/pphb-dgspsp/hcai-iamss/tti-it/pr-re_01_02/ index.html $>$ (Version current at January 19, 2005).

8. Holness L, Knippen MA, Simmons L, Lachenbruch PA. Fatalities caused by TRALI. Transfus Med Rev 2004;18:184-8.

9. American Academy of Pediatrics. Blood safety: Reducing the risk of transfusion - transmitted infections. In: Red Book: Report of the Committee on Infectious Diseases, 25th ed. Elk Grove Village: American Academy of Pediatrics, 2000:88-97.

10. Lee CK, Ho PL, Chan NK, Mak A, Hong J, Lin CK. Impact of donor arm skin disinfection on the bacterial contamination rate of platelet concentrates. Vox Sang 2002;83:204-8

11. West Nile Virus: Transmission through blood. <www.hc-sc.gc.ca/ english/westnile/blood.html\#3> (Version current at January 19, 2005).

12. Busch MP. Closing the windows on viral transmission by blood transfusion. In: Stramer SL, ed. Blood Safety in the New Millennium. Bethesda: American Association of Blood Banks, 2001:33-54.

13. Guertler LG. Virus safety of human blood, plasma, and derived products. Thromb Res 2002;107:S39-45.
14. Laupacis A, Brown J, Costello B, et al. Prevention of posttransfusion $\mathrm{CMV}$ in the era of universal WBC reduction: A consensus statement. Transfusion 2001;41:560-9.

15. Blumel J, Schmidt I, Willkommen H, Lower J. Inactivation of parvovirus B19 during pasteurization of human serum albumin. Transfusion 2002;42:1011-8.

16. Blajchman MA. Incidence and significance of the bacterial contamination of blood components. Dev Biol 2002;108:59-67.

17. Blajchman MA, Goldman M, Baeza F. Improving the bacteriological safety of platelet transfusions. Transfus Med Rev 2004;18:11-24.

18. Seghatchian J. Bacterial contamination of blood components. Transfus Apharesis Sci 2001;25:147-50.

19. Churchill WH, Schmidt B, Lindsey J, Greenberg M, Boudrow S, Brugnara C. Thawing fresh frozen plasma in a microwave oven. A comparison with thawing in a 37 degrees $C$ water bath. Am J Clin Pathol 1992;97:227-32.

20. Chiavetta JA, Escobar M, Newman A, et al. Incidence and estimated rates of residual risk for HIV, hepatitis C, hepatitis B and human T-cell lymphotropic viruses in blood donors in Canada, 1990-2000. CMAJ 2003;169:767-73.

21. Tabor E. The epidemiology of virus transmission by plasma derivatives: Clinical studies verifying the lack of transmission of hepatitis B and C and HIV type 1 . Transfusion 1999;39:1160-8.

22. Preiksaitis JK, Sandhu J, Strautman M. The risk of transfusionacquired CMV infection in seronegative solid-organ transplant recipients receiving non-WBC-reduced blood components not screened for CMV antibody (1984 to 1996): Experience at a single Canadian center. Transfusion 2002;42:396-402.

23. Llewelyn CA, Hewitt PE, Knight RS, et al. Possible transmission of variant Creutzfeldt-Jakob disease by blood transfusion. Lancet 2004;363:417-21

24. Peden AH, Head MW, Ritchie DL, Bell JE, Ironside JW. Preclinical vCJD after blood transfusion in a PRNP codon 129 heterozygous patient. Lancet 2004;364:527-9.

25. Herzog C, Sales N, Etchegaray N, et al. Tissue distribution of bovine spongiform encephalopathy agent in primates after intravenous or oral infection. Lancet 2004;363:422-8.

26. Wilson K, Ricketts M. Transfusion transmission of vCJD: A crisis avoided? Lancet 2004;364:477-9.

\section{INFECTIOUS DISEASES AND IMMUNIZATION COMMITTEE (2004-2005)}

Members: Drs Upton Allen, The Hospital for Sick Children, Toronto, Ontario; H Dele Davies, Michigan State University, East Lansing, Michigan, USA; Simon Richard Dobson, BC's Children's Hospital, Vancouver, British Columbia; Joanne Embree, The University of Manitoba, Winnipeg, Manitoba (chair); Joanne Langley, IWK Health Centre, Halifax, Nova Scotia; Dorothy Moore, The Montreal Children's Hospital, Montreal, Quebec; Gary Pekeles, The Montreal Children's Hospital, Montreal, Quebec; Élisabeth Rousseau-Harsany, Hôpital Sainte-Justine, Montreal, Quebec (board representative).

Consultants: Drs Gilles Delage, Héma-Québec, Saint-Laurent, Quebec; Noni MacDonald, Department of Paediatrics, IWK Health Centre, Halifax, Nova Scotia.

Liaisons: Drs Scott Halperin, IWK Health Centre, Halifax, Nova Scotia (IMPACT); Susan King, The Hospital for Sick Children, Toronto, Ontario (Canadian Paediatrics AIDS Research Group); Monica Naus, BC Centre for Disease Control, Vancouver, British Columbia (Health Canada, National Advisory Committee on Immunization); Larry Pickering, Centers for Disease Control and Prevention, Atlanta, Georgia, USA (American Academy of Pediatrics, Committee on Infectious Diseases).

Principal authors: Drs Noni MacDonald, Department of Paediatrics, IWK Health Centre, Halifax, Nova Scotia; JW Scott, Department of Health, Halifax, Nova Scotia; Ms Nancy McCombie, RN, Manager, Transfusion Transmitted Injuries Section, Blood Safety Surveillance and Health Care Acquired Infections Division, Centre for Infectious Disease Prevention and Control, Public Health Agency of Canada; Dr Antonio Giulivi, Director, Blood Safety Surveillance and Health Care Acquired Infections Division, Centre for Infectious Disease Prevention and Control, Public Health Agency of Canada

\footnotetext{
The recommendations in this statement do not indicate an exclusive course of treatment or procedure to be followed. Variations, taking into account individual circumstances, may be appropriate. This article has also appeared in a previous issue of Paediatrics $\mathcal{E}$ Child Health (Paediatr Child Health 2005;10[3]:149-153)
} 


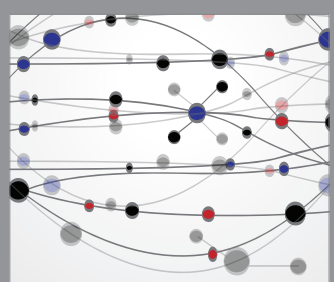

The Scientific World Journal
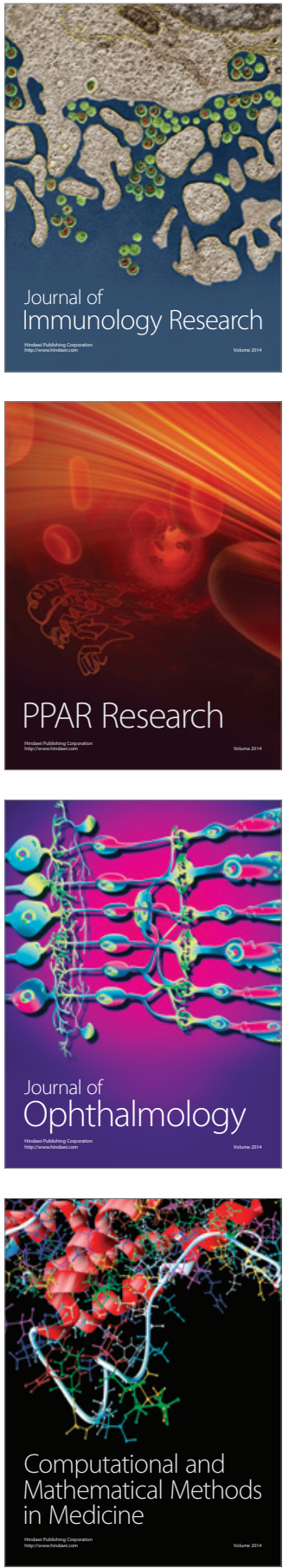

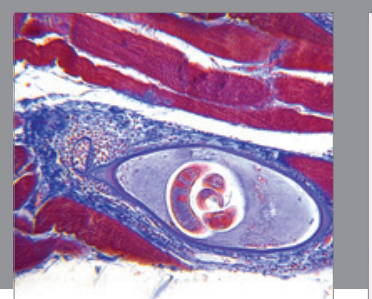

Gastroenterology Research and Practice

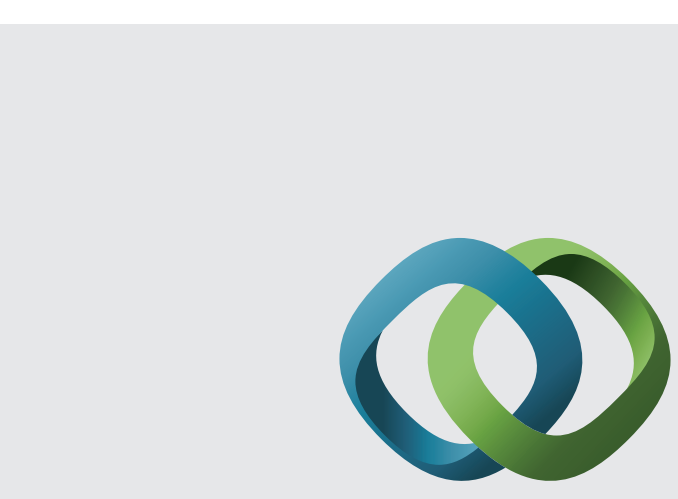

\section{Hindawi}

Submit your manuscripts at

http://www.hindawi.com
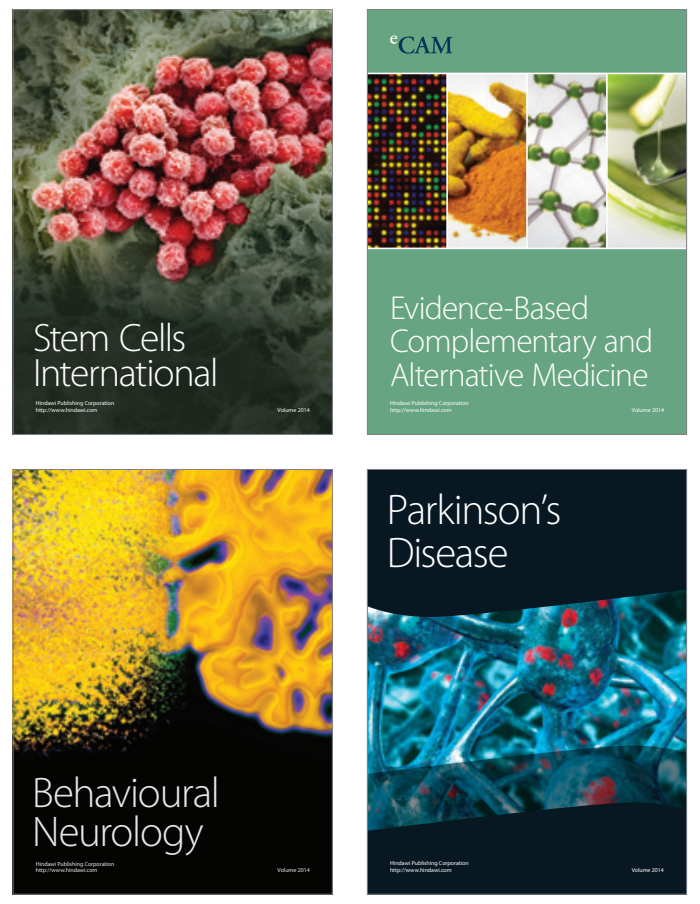
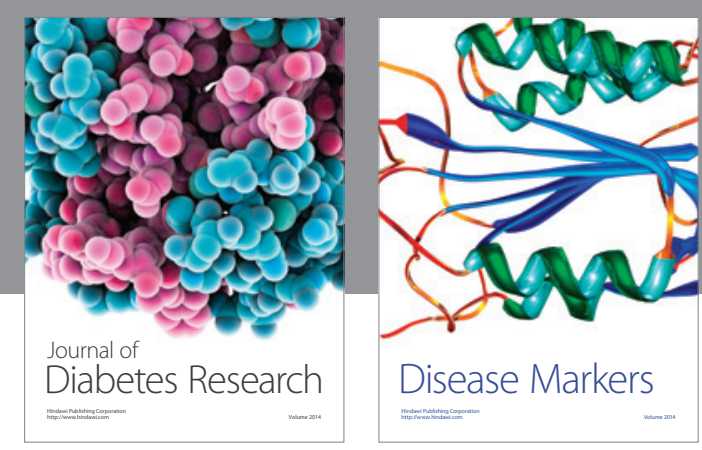

Disease Markers
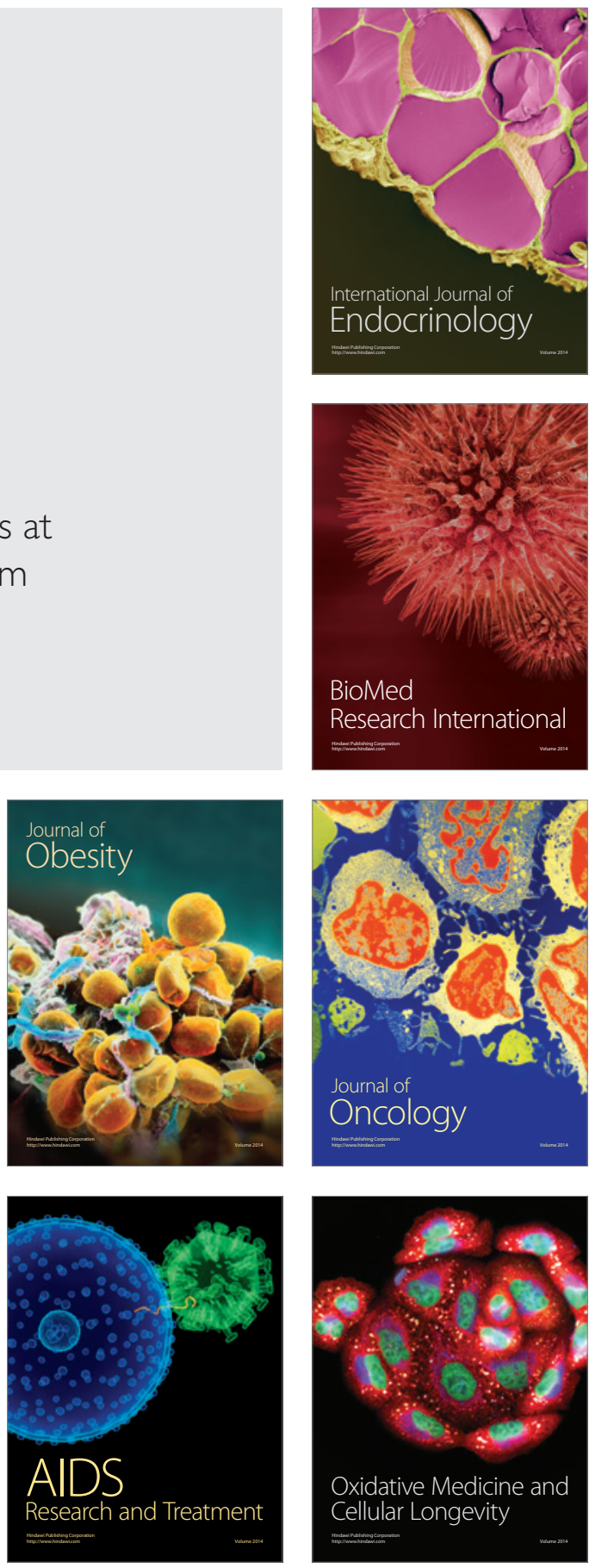